Review

\title{
Soil Fertility Management a Century Ago in Farmers of Forty Centuries
}

\section{Joseph R. Heckman}

Department of Plant Biology \& Pathology, Rutgers, The State University of NJ, 59 Dudley Road-Foran Hall, New Brunswick, NJ 08901, USA; E-Mail: Heckman@aesop.rutgers.edu; Tel.: +1-848-932-6333; Fax: +1-732-932-9441

Received: 18 April 2013; in revised form: 18 May 2013 / Accepted: 13 June 2013 /

Published: 20 June 2013

\begin{abstract}
Published just over a century ago, Farmers of Forty Centuries or Permanent Agriculture in China, Korea, and Japan, served to document the viability and productivity of traditional agricultural systems that relied on composting, and complete recycling of all types of natural waste materials, as a means of sustaining soil fertility. This cardinal rule of waste management and organic soil husbandry became known as "the law of return" to organic farming. With regards to nutrient management, organic farming methods uses restorative cultural practices that include the law of return principle which encourages the closure of nutrient cycles. In these respects, organic farming methods are arguably more firmly grounded in ecology and sustainability than the promotions of the chemical fertilizer industry which has largely displaced traditional soil fertility practices. Farmers of Forty Centuries is a classic with valuable lessons and experience to offer towards teaching modern concepts in sustainable agriculture.
\end{abstract}

Keywords: China; Korea; Japan; sustainability; permanent agriculture; organic farming; soil fertility; livestock and human manure; law of return; F.H. King

\section{Introduction}

Published just over a century ago, Farmers of Forty Centuries or Permanent Agriculture in China, Korea, and Japan [1], is regarded as a classic among advocates for organic farming [2]. The author, F.H. King was a soil scientist once employed by the USDA. In the book, King chronicles his observations on how farmers in the parts of Asia where he traveled, effectively utilized every type of natural waste material-including livestock and human manures, crop residues, ash, and sediment 
from canal dredging - as soil amendments. Literally no natural "waste" product was wasted. Compost piles were common sights and were photographed by King in many parts of China. The book is heavily illustrated with King's photographs.

Valuable reviews of the pioneering scientific work [3,4] of F.H. King and his influential agricultural classic have been published elsewhere. The primary purpose of this review is to discuss the significance of Farmers of Forty Centuries in relation to soil fertility, nutrient management, organic farming, and sustainability.

\section{Results and Discussion}

Although this 441 page volume may be an obscure text among modern agricultural scientists, it was quite influential in the early organic farming movement where it became a classic. The vitally important soil fertility principle of returning organic waste materials to soil became a widely adopted creed of organic farming pioneers. Building on King's observations, Sir Albert Howard developed a method of composting during the 1920s based on his agricultural research conducted in India. Howard was an important figure in the organic farming movement and promulgated this cardinal rule of waste management and organic soil husbandry as "the law of return". The writings of both King and Howard were influential in the development of organic farming systems in the United States [5].

The practice of fully utilizing all types of natural waste materials was deeply ingrained in Eastern culture. King describes their conservation of natural resources as an "inherited instinct". In several passages King writes about the beneficial use of human manure. Here is one such paragraph: "Among the most common sights on our rides from Yokohama to Tokyo, both within the city and along the roads leading to the fields, starting early in the morning, were the loads of night soil carried on the shoulders of men and on the backs of animals, but most commonly on strong carts drawn by men, bearing six to ten tightly covered wooden containers holding forty, sixty or more pounds each. Strange as it may seem, there are not today and apparently never have been, even in the largest and oldest cities of Japan, China or Korea, anything corresponding to the hydraulic systems of sewage disposal used now by western nations. Provision is made for the removal of storm waters but when I asked my interpreter if it was not the custom of the city during the winter months to discharge its night soil into the sea, as a quicker and cheaper mode of disposal, his reply came quick and sharp, 'No, that would be a waste. We throw nothing away. It is worth too much money.' In such public places as railway stations provision is made for saving, not for wasting, and even along the country roads screens invite the traveler to stop, primarily for profit to the owner, more than for personal convenience."

In another brief passage King eloquently and succinctly draws a striking contrast in soil fertility management between the East and the West: "The human waste must be disposed of. They return it to the soil. We turn it into the sea." Here it should be noted that even today with modern sewage treatment plants where sewage biosolids are recovered, much of the soluble $\mathrm{K}$ continues to flow to the sea and much of the volatile $\mathrm{N}$ is lost to the atmosphere. Also, in the case of $\mathrm{P}$, it is often precipitated with $\mathrm{Fe}$ or $\mathrm{Al}$ additives that render it less available for plant uptake [6]. Finally new research is underway that may replace the flush toilet and find better ways to recover the nutrients contained in human waste [7]. 
Throughout the book King documents and enumerates typical crop yield levels, cultural practices, and NPK inputs on the land from various amendments including composts, mulches and ash. By today's standards, crop yield levels reported from a century ago were not necessarily low or unacceptable. Farmers of Forty Centuries serves to document the potential productivity of agroecosystems when crops were intensively managed with high levels of human labor. One of the great changes of the last century is a reduction in the amount of human and animal labor going into modern food production. The labor reduction as a lifestyle change is not necessarily accompanied by increased productivity.

Another major change has been the widespread adoption of commercial fertilizers as an alternative to composting. In 2011, I traveled in China to attend the International Conference on Silicon in Agriculture [8]. Although my travels were limited compared to King's, I did not see evidence of composting anywhere. The displacement of the law of return [9] and composting as cultural norms with commercial fertilizers on a global scale has supplanted a wise tradition.

King often gives details of the NPK contents of the various waste materials being land applied. During the period in which he was writing there was little attention given to the value of other plant nutrients in these waste materials or anti-fertility factors such as heavy metals.

While the value of organic carbon from waste materials is generally recognized, the modern focus on nutrient management in the United States is still lacking an ecological orientation. Unbalanced nutrient flows and excess nutrient accumulations around concentrated animal feeding operations are a consequence and a prime example of an industrial structure that ignores ecology [10].

With regards to nutrient management, organic farming methods use restorative cultural practices that include the law of return principle which encourages the closure of nutrient cycles. In this respect, organic farming methods are more firmly grounded in ecology and sustainability than is the fertilizer industry "4R Nutrient Stewardship" promotion [11] which places little emphasis on nutrient cycling and ignores the law of return principle.

The widespread displacement of compost and the law of return principle with modern commercial fertilizers sometimes fail to resupply the full complement of vital elements needed by both plants and animals. Modern commercial fertilizers do very little to build soil organic matter content and soil quality [12]. Silicon, for example, is now recognized as a beneficial substance for plants but it is not usually included in commercial fertilizers. Supplementing soil with silicon suppresses plant diseases, protects crops from insect attack, and increases tolerance to abiotic stresses [13]. Soils can become depleted of silicon fertility as a result of continued crop removal. The return of waste materials to soil not only replenishes valuable amounts of silicon; it also feeds microbial activity which plays a role in mobilizing nutrients for plant uptake.

The organic farming community has for a long time decried missing soil fertility factors of commercial fertilizers and at the same time extolled the valuable soil-quality-building attributes of compost [14]. Composting and practicing the law of return principle, however, can also fail to correct a deficiency of an essential nutrient when a specific nutrient is lacking in the local soils. The ability to correct such deficiencies is where commercial fertilizers clearly play an important role. The USDA National Organic Program [15] addresses for this need and allows for micronutrient deficiencies identified by soil and plant analysis to be supplied using approved commercial fertilizer products. 
They supply needed $\mathrm{P}, \mathrm{K}, \mathrm{Ca}$, or $\mathrm{Mg}$, when not enough can be provided by compost by using natural mined rock powders.

The organic community has been instrumental in keeping King's book in circulation. King's manuscript was originally published by his wife and was later republished without any change in wording by the Rodale Press. However, a 2004 Dover edition unfortunately changed the title by replacing the words "Permanent Agriculture" with "Organic Farming". Although the organic community has embraced this agricultural classic, the title change was inappropriate for historical accuracy. Also in some instances King mentions where ammonium sulfate and superphosphate fertilizers were coming into use. These are prohibited inputs by current USDA organic standards and therefore further make the 2004 title inappropriate.

Anytime natural waste materials are landfilled instead of being composted, it is a lost opportunity to build soil quality and fertility. On a geological time scale, nutrient elements, even if buried in a land fill, will eventually re-enter their natural cycles. And in a geological timeframe, it may matter little that humans neglect the law of return principle of organic farming. However, it may be argued that even within the timeframe of a human life, we suffer the social consequences of less fertile soil. Besides social consequences, there are many important implications for human health in connection with soil quality as described in a new book entitled Soils and Human Health [16].

Around the same time in the last century as traditional systems of soil fertility using compost were being displaced by commercial fertilizers, traditional food systems were similarly being displaced by what Weston A. Price called the "displacing foods of commerce". In his 1939 book, Nutrition and Physical Degeneration, Dr. Price documents the unfortunate decline in dental and human health in general that is associated with replacing traditional foods in the diet with modern industrially processed and refined foods [17]. Thus, whether it is for soils or people, there are ecological and health benefits to traditional means of nourishment. It is primarily within organic food and farming communities where the consequences of these modern degenerating transformations on soil health and human health are recognized and addressed [18].

Interestingly, the modern emphasis on sustainable agriculture and sustainability do not appear in these direct terms anywhere in this book. Only once does the root of "sustainable" appear in the text as in this passage "more than forty unbroken centuries of farmers who, with brain and brawn, have successfully and continuously sustained large families on small areas without impoverishing their soil." Clearly King was just as concerned with what we now call sustainability. Later in the book he writes: "If the United States is to endure; if we shall project our history even through four or five thousand years as the Mongolian nations have done, and if that history shall be written in continuous peace, free from periods of wide spread famine or pestilence, this nation must orient itself; it must square its practices with a conservation of resources which makes endurance possible." Also, King references the work of a fellow soil scientist from the United States, Dr. Hopkins [19] who had recently published Soil Fertility and Permanent Agriculture. "Permanent" is a key word in that book title as well. So in other words, and as the title Farmers of Forty Centuries or Permanent Agriculture in China, Korea, and Japan implies this timeless book is all about sustainability and it has valuable lessons and experience to offer towards teaching modern concepts in sustainable agriculture. 


\section{Conclusions}

Today it is generally assumed that modern levels of agricultural productivity could not be achieved without extensive use of chemically manufactured fertilizers [20,21]. However, a reading of Farmers of Forty Centuries may lead one to at least begin to question that assumption. The centuries old observations in this book are worth reading and revisiting in the context of what kinds of agricultural wisdom may have been lost with modernization and the introduction of commercial fertilizers on a massive industrial scale.

\section{Conflict of Interest}

The author declares no conflict of interest.

\section{References}

1. King, F.H. Farmers of Forty Centuries or Permanent Agriculture in China, Korea, and Japan; Rodale Press: Emmasus, PA, USA, 1911.

2. Paull, J. Permanent Agriculture: Precursor to Organic Farming. Elem. Biodyn. Tasman. Available online: http://orgprints.org/10237/1/10237.pdf (accessed on 6 March 2013).

3. Paull, J. The making of an agricultural classic: Farmers of forty centuries or permanent agriculture in China, Korea and Japan, 1911-2011. Agric. Sci. 2011, 2, 175-180.

4. Tanner, C.B.; Simonson, R.W. Franklin Hiram King-Pioneer Scientist. Soil Sci. Soc. Am. J. 1993, 57, 286-292.

5. Heckman, J.R. A history of organic farming: Transitions from Sir Albert Howard's war in the soil to USDA national organic program. Renew. Agric. Food Syst. 2006, 21, 143-150.

6. Brady, N.C.; Weil, R.R. The Nature and Properties of Soils; Prentice Hall: Upper Saddle River, NJ, USA, 2008.

7. Gretchen, V. Finding a better way to go. Science 2012, 337, 673.

8. Proceedings of the 5th International Conference on Silicon in Agriculture. Available online: http://www.silicon-nutrition.info/Proceedings2011.pdf (accessed on 6 March 2013).

9. Heckman, J.R.; Weil, R.; Magdoff, F. Practical Steps to Soil Fertility for Organic Agriculture. In Organic Farming: The Ecological System; Francis, C., Ed.; American Society Agronomy, Crop Science Society America, Soil Science Society America: Madison, WI, USA, 2009; Agronomy Monograph 54.

10. Coleman, E. Organic agriculture: Deeply rooted in science and ecology. Available online: http:/grist.org/sustainable-farming/2011-04-20-eliot-coleman-essay-organic/ (accessed on 6 March 2013).

11. Sustainability in Agriculture: The Right Place \& Right Time. Available online: http://www.croplife.com/article/24937/sustainability-in-agriculture-the-right-place-right-time (accessed on 6 March 2013).

12. Mulvaney, R.L.; Khan, S.A.; Ellsworth, T.R. Synthetic nitrogen fertilizers deplete soil nitrogen: A global dilemma for sustainable cereal production. J. Environ. Q. 2009, 38, 2295-2314. 
13. Provance-Bowley, M.; Heckman, J.R.; Durner, E.F. Calcium silicate suppresses powdery mildew and increases yield of field grown wheat. Soil Sci. Soc. Am. J. 2010, 74, 1652-1661.

14. Hepperly, P.; Lotter, D.; Ziegler-Ulsh, C.; Seidel, R.; Reider, C. Compost, manure and synthetic fertilizer influences crop yields, soil properties, nitrate leaching, and crop nutrient content. Compost Sci. Util. 2009, 17, 117-126.

15. USDA National Organic Program. Available online: http://www.ams.usda.gov/AMSv1.0/nop (accessed on 6 March 2013).

16. Brevik, E.C. Soils and Human Health-An Overview. In Soils and Human Health; Brevik, E.C., Burgess, L.C., Eds.; CRC Press: Boca Raton, FL, USA, 2013; pp. 29-53.

17. Price, W.A. Nutrition and Physical Degeneration; The Price-Pottenger Nutrition Foundation: La Mesa, CA, USA, 1939.

18. Balfour, E.B. The Living Soil and the Haughley Experiment; Universe Books: New York, NY, USA, 1976.

19. Hopkins, C.G. Soil Fertility and Permanent Agriculture; Ginn and Company: Boston, MA, USA, 1910.

20. Erisman, J.W.; Sutton, M.A.; Galloway, J.; Klimont, Z.; Winiwater, W. How a century of ammonia synthesis changed the world. Nat. Geosci. 2008, 1, 636-639.

21. Charles, D. The curse of fertilizer. Natl. Geogr. 2013, 223, 94-111.

(C) 2013 by the authors; licensee MDPI, Basel, Switzerland. This article is an open access article distributed under the terms and conditions of the Creative Commons Attribution license (http://creativecommons.org/licenses/by/3.0/). 